\title{
The Role of the Agent Bank and the Specificity of Its Legal Status in the Syndicate Loan (A Comparative Study)
}

\author{
Mohammed Shein Al-kateb ${ }^{1}$, Noor Akief Al-Dabbas ${ }^{1}$ \& Qais Enizan Al-Sharaiyri ${ }^{2}$ \\ ${ }^{1}$ Amman Arab University, Amman, Jordan \\ ${ }^{2}$ Irbid National University, Irbid, Jordan \\ Correspondence: Mohammed Shein Al-kateb, Amman Arab University, Amman, Jordan.
}

\author{
Received: March 1, 2018 \\ doi:10.5539/jpl.v11n4p123 \\ Accepted: April 26, $2018 \quad$ Online Published: November 30, 2018 \\ URL: https://doi.org/10.5539/jpl.v11n4p123
}

\begin{abstract}
This study dealt with one of the most important parties to the syndicate loan contract which is the agent's bank, which is entrusted with the task of managing the daily loan. The task of this bank begins immediately after the end of the work of the organized bank and signing of the loan contract by its parties. The role of the agent's bank in the syndication loan was determined through this study, starting from appointing it through the tasks entrusted to it and ending with the termination of its powers and throughout the term of the loan, the role of this bank is a set of legal relations. The parties to the loan contract have certain specificity with respect to the responsibility of each party towards executing the contract in accordance with the agreed provisions and the required standards. This research requires the legal status of this bank in accordance with the different legal principles in the countries in which this loan originated, as well as the orientations of banks in the international markets. Accordingly, these relations were rooted in Jordanian law in the absence of legislation regulating syndicated loan contracts and the role of the agent bank. This study concluded that this bank is considered a special agent unless the Bank makes the same agent expressly - conclusively or factually - in a position that renders it liable to one of the parties for the duties of the agency for which the confidence of the secretariat is subdivided.
\end{abstract}

Keywords: Syndicate loan, agent bank, legal status

\section{Introduction}

Syndicated bank loans are one of the main sources of domestic and international financing for large public and private sector projects. This credit facility has allowed lenders - internationally - to provide financing amounts of approximately $\$ 4.5$ trillion in one year, which is nearly one-third of the world's funding needs that year (Altunbas, et al., 2006).

In syndicated bank loans, a group of banks and financial institutions cooperate to finance a borrower with its large amounts of financing that banks can not individually provide to lenders. ${ }^{1}$ It is therefore a multi-bank transaction (Mugasha, 2007). ${ }^{2}$

Due to the length of the procedures required by the loan arrangement process to prepare the loan documents and the collection of the participating banks, the process of regulation has been assigned to a bank or a professional financial institution to carry out this role called the "regulator", which ends its role by signing the facilitation agreement between the borrower and the participating banks, who manages and deals with the borrower after signing the facility agreement throughout the lifetime of the loan until it ends in payment or any other method of completion. The task of managing the daily loan has been assigned to a bank or financial institution called "agent" which shall commence its duties immediately after the end of the work of the regulated bank and the signing of the loan contract by its parties.

The objective of appointing the agent bank in the syndication loan is to avoid the logistical difficulties that can be faced by both lenders and borrowers in the absence of such bank, especially when the facilities are large and

\footnotetext{
${ }^{1}$ The single bank can not provide loans and credit facilities with very large amounts to one borrower due to internal and external control constraints, limiting its ability to do so. The syndicate loans have enabled lenders to cooperate with each other to finance these large amounts and thereby distribute risks lending to a number of them instead of being borne by one bank individually.

${ }^{2}$ Multi-bank banking operations, in which two or more financial institutions cooperate, to provide financing to a borrower, such as Syndicated loans, Participation Loans or other transactions.
} 
include tens or hundreds of lending banks (Adams, 2014), the participating banks that have signed the loan with the Borrower shall then appoint the Agent to act on its behalf as an administrative agent in the day-to-day running of the Loan in the face of the Borrower and to act as a channel to transfer information and funds between the Borrower and the Lenders participating, and as a general coordinator among all lenders involved in the syndication loan to facilitate important decision making processes related to the loan (Wight, 2009).

\subsection{Research Problem}

The problem of this study is to determine the nature of the legal relationship between the agent bank and the parties of the syndicate loan contract during the period of its management of the syndicate loan. This is done by examining the solutions provided by the jurisprudence and the Anglo-Saxon law for this problem. And assess the extent to which these solutions are compatible with the orientations of banks in the international markets, in addition to the possibility of the withdrawal of these solutions to the environment of Jordanian law in the absence of legislation regulating the contracts of the bank loan and the role of the bank agent.

\subsection{Question of the Study}

This study attempts to answer the following question:

What is the role of the agent bank and the specificity of its legal status in the syndicate loan?

\subsection{Research Objective}

This study shed light on the role played by the agent's bank in the loan of the banking group starting from appointing it through the tasks entrusted to it and ending the termination of its powers in this loan and then discussing the legal status of this bank in accordance with the various legal and judicial Anglo-Saxon legal perspectives; the countries in which this loan originated.

\section{Methodology}

The descriptive and deductive approaches were adopted to describe the stages of the stage of organizing the syndicate loan and the principles on which the bank's loans are based, and to reach the agreed jurisprudence, the judiciary and the contractual models in determining the legal status of the agent bank in the syndication loan, as well as the comparative approach that imposes itself in such studies.

This study is divided into three topics. The first topic dealt with the definition of the syndicate loan and the main principles on which it is based. The second part dealt with the stages of regulating the syndicate loan and the role of the bank organized according to the views of jurisprudence and the Anglo-Saxon judiciary, with a statement of the position of the model contract issued by the Union of the Loan Market (LMA) ${ }^{3}$, with a statement of the position of Jordanian law on this issue.

\subsection{The Core of the Syndicated Loan}

In this section the researchers gave a quick overview of the origin of the syndicated loans and its development, then provided a definition of this loan and finally showed the parties to the bank loan agreement.

\subsubsection{The Emergence of Syndicated Bank Loans}

The syndicated bank loans are relatively modern, the jurisprudence differed on the precise date of the establishment of this loan between those who originated in the middle Ages and those who believe that it was a newly formed contract that was conceived in the United States of America and then moved to the Euro - Dollar markets (Khatib, 2015).

However, the dominant view is that the syndicated bank loans have emerged - in their simple form - in London after the Second World War as part of Euro-dollar loan contracts(Rhodes \& O'Donovan, 2009), (Khatib, 2015). In this relatively short period of time, the financing tool grew, diversified, and become more complex to meet all the needs of the lenders from financing to becoming one of the most important sources of financing at the local and international levels (Altunbas, Yener et al., 2006).

\footnotetext{
${ }^{3}$ The Loan Market Association (LMA) was established in 1996 by a group of leading international banks and financial institutions in Europe and was headquartered in London. This association is responsible for laying the foundations and criteria for regulating multi-bank lending operations are those that take place in primary markets- which are carried out in the primary markets - that is, between the major lenders and the borrowers - or the sale and circulation of these loans in the secondary markets. This union may cover the European market countries and the Middle East and North Africa, where the number of members until the date of writing This study is made up of 576 members from 56 banks and institutions for financial and corporate law firms.
} 


\subsubsection{Definition of Syndicated Loan}

The syndication loan contract can be defined as: "credit" - this description is used instead of the term "loan" because the joint banking market offers products other than loans ${ }^{4}$ under which two or more financial institutions - banks or other non-bank investors the lenders must combine - to contract with a borrower to grant credit - usually the medium term - on terms and general terms governed by a common document ${ }^{5}$. (Rhodes, Tony (2009)

\subsubsection{The Parties to the Syndication Loan Contract}

The Bank's syndicated loans include a number of parties: Borrowers, the organized bank, the agent bank, and the participating banks. This requirement will be divided into four items, each of which will be allocated to one of these parties, as follows:

\subsubsection{The Borrowers}

Borrowers use syndicated loans to cover their large financing needs, which are larger than the capacity of a single bank. It is therefore unthinkable that the borrower in the syndication loans is a natural person, but usually a judgmental person. The borrowers can therefore be divided into two categories:

The first category: The Sovereign Sector: Countries, governments, and public sector institutions that enjoy financial and administrative independence. This category also includes intergovernmental organizations such as the World Bank and regional development banks.

The second category: is the private sector: financial institutions (IF's), such as commercial and investment banks, mutual funds, and hedge funds, or large commercial companies that work in infrastructure projects such as oil and gas projects and energy of various types and projects of telecommunications and other sectors (Mugasha, Agasha (2007), and (Rhodes, Tony).

\subsubsection{The Arrangers}

The bank that manages the pool facilities is known as the Ranger Bank or Leading Bank, and is called the Lead Manager, the Syndicate Lead or the Mandated Lead Arranger (MLA) (Pamsaj, P24). The regulator's task begins when the borrower receives a written authorization (Adams, David, 2014) and the regulator can be a commercial or investment bank (Pankaj, 2015). Which is authorized by the syndicate's loan organization, and ends with the signing of the loan agreement between the borrower and the lenders participating in the assembly (Wright, Sue, P210).

The main task of this bank is to prepare the syndicated loan documents, advise the borrower on what suits him and his project of various types of facilities, search for banks involved in the financing of the loan and the composition of the group, discuss the terms of the loan with the borrower and the banks participating in the financing (Adams, David, 2014), and (Mugasha, Agasha, 2007).

\subsubsection{Agent Banks}

In order to avoid the logistical difficulties that can be faced by the borrower and the lenders, the banks agreed to assign the task of dealing with the borrower and managing day-to-day running of the loan throughout the life of the loan to a bank called the agent The administrative agent, which is briefly called the Agent Bank or The Agent. In order to assess the importance of the role played by the agent bank in the syndication loans, we can imagine the difficulties that banks can face in dealing with the borrower in case the lack of the existence of this bank and in particular when the facilities are large and include tens or hundreds of the lending banks (Adams, 2014) (Wight, 2009).

The role of the agent bank begins as soon as the role of the regulated bank ends, ie when all parties sign the loan agreement and its documents. The important fact that some borrowers may overlook - especially when dealing with syndicated bank loans for the first time - is that the agent bank is an agent for the lenders and not an agent for the borrower (Abubakari, 2012), (LMA, 2009).

\footnotetext{
${ }^{4}$ The phrases between the two axons are present in the body of the definition itself, where the researchers transferred them as they were presented.

${ }^{5}$ This definition is due to the researcher Tony Rhodes, which he defined as follows:

A syndicated credit (this term, rather than "loan", is used because the syndicated banking market offers products other than loans) is one in which two or more institutions (banks or other non-bank investors, collectively the syndicate of lenders) contract with a borrower to provide (usually medium-term) credit on common terms and conditions governed by a common document. (Rhodes, tony (2009) ,P17)
} 


\subsubsection{Participants}

Not all participants in syndication loans are always in the same rank. Their ranks may vary depending on the type and size of the loan, depending on the size of their participation and the nature of the role assigned to them under the facility agreement. : 1) Managers, 2) Co-Managers, 3) Ordinary Participants and 4) Investors.

Non-bank financial institutions' contribution to bank loans and secondary loan markets increased significantly. These financial institutions, for the time being, provide almost half of the liquidity available in secondary loan market operations (Mugash, Agasha, 2007).

It is recognized that allowing non-bank financial institutions to invest their money in loans varies from one country to another and from one legal system to another. This is determined by laws, regulations and instructions and in some countries by the competent authorities for granting permits (Wood, Philip, 2007).

\subsection{Stages of Arranging the Syndication Loan and the Role of the Agent Bank}

The agent's bank has a role in each stage of the bank assembly, which requires the statement of this role to review these stages in the first demand and then to explain the role of the agent bank at each stage with a second request.

\subsubsection{Stages of Organizing a Syndication Loan}

Most of the studies agree on dividing the phases of organizing the syndicate loan into three basic stages. Each stage includes a number of steps ${ }^{6}$. The first and second stage will be presented with some briefness because they do not belong to the agent bank but belong to the organized bank, the third phase will be presented in details because it belongs to the Agent bank:

\subsubsection{Pre-mandate Stage ${ }^{7}$}

In this stage preparations are made to organize the syndication loan (probable). Where the borrower takes its procedures and decisions, as well as negotiations between the borrower and a number of banks nominated to organize the syndicate loan, ending with the submission of the nominated banks to the borrower, the borrower chooses the offer that suits him and gives the bank that submitted this offer the letter of authorization (The Mandate Letter), which authorizes the organization of the syndicated bank loan and the collection of banks (Rhodes, Tony, p220-227, Halak, Issam Schure, Paul, 2009.4) and Shutter, Andrew etal (2010), P121).

\subsubsection{Post-mandate Stage ${ }^{8}$}

This stage is called post-issuance phase of the authorization letter or general syndication stage, because at this stage the process of preparing the loan documents and collecting the participating banks to provide their shares in the amount of funding is completed. This stage ends when all the banks that decided to participate Loan agreement with the borrower (Hallak, Issam and Schure Paul (2009), p4-5). This stage is critical for both the regulated bank and the borrower, since each has committed itself to the actions and procedures required to obtain the desired financing, so both are at risk of not being identified - the risk of unfinished loan procedures (Godlewski, Christophe) (2009), p. 2).

This phase includes a number of steps, the most important of which are the Due diligence ${ }^{9}$, the preparation of the information note ${ }^{10}$, the structuring of the loan ${ }^{11}$, the marketing of the loan (by sending invitations, receiving

\footnotetext{
${ }^{6}$ It should be noted that the arrangement of these steps and stages is not mandatory, but it is just a regulatory process of the banks have been able to shorten some of them or provide a step on another, depending on the type of loan and size and the circumstances of the process of regulation, where many studies indicate that The methods of preparation and composition of the syndicated bank loan vary according to the type and size of the loan, the conditions of the lending process and the methodology used in that market, and some studies are reduced in two stages only, the pre-signing of the contract and the post-signing of the contract, But the researchers took the majority of the references and divided it into three phases please see the following references: Armstrong, Jim, (2003), (Rhodes, Tony, Halak, Issam \& Schure, Paul, 2009.p) and (Shutter, Andrew etal (2010).

${ }^{7}$ This period can take of one month to one year.

${ }^{8}$ This stage can take between two to six months.

9 Due diligence is a term used to express a number of concepts that include procedures for in-depth examination or verification of a particular business, or of a particular person before contracting or engaging in a work requiring a certain degree of care. The types of invasive examination of ignorance vary in many areas depending on what is desired

${ }^{10}$ An information note (IM) is a core document of a bank loan that is attributed to the borrower as a promise (Godlewski, Christophe (2009). This memo is being prepared in coordination between the bank and the borrower. In some cases, the draft is prepared by the bank based on the information obtained from different sources, such as by the borrower directly or through the process of non-disclosure, which is regulated by official bodies such as the central bank - if the borrower is sovereign - but is attributed to a borrower (Twinamatsiko, Francis N., p4) and (Rhodes, Tony, 2009). The organizer uses this memo as a key document in the syndication loan bank, where he sends them to banks that have
} 
responses, and the process of allocation), and the preparation of the Facility Agreement ${ }^{12}$, and discuss them with the nominated banks ... and so on until the parties have signed the Facility Agreement ${ }^{13}$.

\subsubsection{Post-sing-the Loan Contract}

This stage begins immediately upon the signing of the syndicated loan contract by the parties and is monitored throughout the lifetime of the loan. In which the agent bank is appointed to exercise its functions and administrative powers and to deal with the borrower on behalf of all the banks participating in the banking group.

\subsubsection{The Role of the Agent Bank in the Syndication Loan}

In this requirement, the role of the agent's bank from the moment of its appointment through its duties, powers, rights and compensation will be explained to the end of this role by the end of the loan or by its resignation or isolation. Accordingly, this subject will be divided into four items as follows: First: the appointment of the agent bank, second: the duties and powers of the agent bank, and third: the rights of the agent bank and compensation, and the fourth item: the resignation or isolation of the agent bank.

\subsubsection{Appoint the Agent Bank}

The role of the agent bank shall commence in the syndication loan as from the date of signing the loan agreement and ends at the end of the agreement either by full payment or by any legal way of completion. And that it is the lenders and the participating financial institutions who appoint the agent bank to act as an administrative agent on their behalf, the main task of the agent is to act as a conduit for the transfer of information and money between the participating banks and the borrower, and vice versa, throughout the life of the loan (Al-Khatib, 2015).

The Agent Bank is the agent of the lenders, as the LMA (Model Contract) explicitly affirmed (Rhodes, Tony (2009). In large loans, a number of banks can be appointed to assist the bank in carrying out its work, each of which has its own special tasks (LMA, 2009, p2). Many studies suggest that in practice, the Arranger bank often operates as an agent bank (Abubakari, 2012).

\subsubsection{The Duties and Powers of the Agent Bank}

When the Agent bank assumes its duties, it has the right to reserve any of the documents through the legal opinion submitted to the banks of the association, which is one of the main conditions for the effectiveness of the loan agreement "(Abdullah \& Al-Trad, (2011).

The first tasks to be addressed by the agent after the signing of the agreement are to verify that all precondent conditions are fulfilled. These conditions, as it appears, are a set of conditions that borrower banks require from the borrower to Complete and achieve before the implementation of the Facility Agreement and receive the first installment of it: such as obtaining a decision from the Board of Directors to approve the terms of the loan and to sign the Facility Agreement and its documents, and to identify the authorized signatories of the loan and obtain the approval of the General Authority - if the borrower is a company - to place its assets as collateral for the loan, and control to take the necessary guarantees and to obtain the necessary approvals from the General Authority of

shown an interest in participating The preparation of a draft memorandum of information (Godlewski, Christophe (2009), (Woods, Philip R. (2007)

${ }^{11}$ The structure of the loan is to determine its type and conditions and to set interest rates, margins and commissions commensurate with the market situation, the risks surrounding the borrower and the lending process.

12 The syndication agreement is the main document that establishes the contractual relationship between the borrower and the banks involved in the financing of the loan on the one hand, and the relationship among the participating banks on the other hand, (Odianosen, Eigbe, 2005). In bilateral loans The lender is responsible for drafting the loan agreement, while in syndication loans, the syndication loan agreement is prepared by the leading bank (the regulator), which is assisted by one of the law firms with experience and expertise in preparing the bank loan agreements. The syndication loan agreements are a special case that is almost different from any other syndicated lending process (Wright, Sue, 2006). The LMA was established in London in 1996 in London and initiated in 1999 the proposed models for bank loan contracts of various types to assist banks in this task. These models have been discussed and scrutinized by a number of experts and lawyers who represent major borrowers and lenders. These models have been widely accepted by lenders and borrowers in the European, Middle East and North African markets and have been used as the basis for syndicated loan agreements, amendments necessary to conform to their conditions and with the conditions to which they conform on them. (Wright, Sue (2006).

${ }^{13}$ After the organizer bank has completed the necessary amendments to the facility agreement and its final documents, as agreed by the banks participating with the borrower, and ends the process of allocation of shares to be shared by banks, agree with all parties to the signing ceremony and set a date. Consistent announcements of the loan are published in some financial journals and newspapers. This advertisement includes information about the borrower, the size of the loan and the principal parties involved. This process is called Tombstone (Adams, 2014). 
the guarantor - if it is a company - to ensure facilities, and to supervise the organization and implementation of complex security packages (insurance products) and examine the prerequisites for them and approval, and ensure that All documents relating to the borrower comply with their legal requirements (Adams, 2014), (Khatib, 2015).

One of the main tasks of this bank is also to enable the borrower to make a withdrawal from the loan or to make the first withdrawal from it if the loan is in installments when the borrower has completed the required preconditions. The agent collects the payments from the participants, delivers them to the borrower, receives the payments from the borrower and distributes them to the participants. He also carries out his duties in maintaining loan accounts and calculating interest, and keeping books for participants and their accounts. And keep the file of correspondence issued and received by the borrower and participants, and to inform them (LMA, 2009).

In addition to maintaining a file with guarantees and follow-up, and follow-up the loan and the borrower and coordinate the relationship of the borrower with the lenders, and coordination among the members of the association throughout the life of the loan, and the media participants about the status of the breach, if any, and coordination between the members of the assembly (Dawood, 2010) and (Abdullah, \& Al-Trad, 2011). It is also his duty to maintain the safety packages - insurance policies - effective throughout the lifetime of the loan and renew the insurance on the dates specified (Fight, 2004).

The agent bank is not responsible for assessing the creditworthiness of the borrower or for verifying the accuracy of the information contained in the borrower's documentation. It is the responsibility of each participating bank, but it must immediately pass any information or observations it receives - related to the loan or borrower - to the participating banks, and if it is found that the borrower has become an Event of Default ${ }^{14}$, he must inform the participating banks immediately (Rhodes, 2009).

The Agent bank's role in the syndicated bank loan contracts has become very specialized and is defined under precise terms called "Agency" clauses which explicitly state that the bank is not subject to the duties of the trust required of ordinary agents under the Agency's law (Wright, 2004).

This is clearly evidenced by reference to the model of the syndicated bank loan contract proposed by the LMA, where paragraph (2) of Article (26) provides for the duties entrusted to the agent bank under the title of "Duties of the Agent" which can be summarized in the following tasks:

a. Examine the contract of the loan and ensure the safety of its terms from the legal point of view and the completion of the preconditions.

b. Receiving notices from the Borrower and distributing them to participating banks and vice versa.

c. Receiving documents, data and financial information from the borrower and delivering it to participating banks.

d. Receiving funds from the lenders and delivering them to the borrower, receiving the payments from the borrower and distributing them to the lenders.

e. Determining the interest rate and recalculating it in the specified periods.

f. Follow up the borrower and notify the lenders involved immediately after a breach by the borrower.

g. Work under the assembly instructions issued by the appropriate majority specified by the contract.

h. Exercise the powers granted to him to expedite the loan at his discretion regarding the occurrence of default by the borrower (in case of emergency) ${ }^{15}$ (Khatib, 2015).

\subsubsection{The Rights of the Agent and His Compensation}

The Bank's syndicated loan contracts include material specifying the rights of the agent's bank and its remuneration for administrative services performed on behalf of the participating lenders. These contracts also provide that the lenders compensate the agent for any liabilities, losses, damages, administrative expenses or fees (Including without limitation the attorneys' fees and related expenses) as a result of the performance of the work entrusted to him (Al-Khatib,2015).

This is stated in Article (26) of the Model Contract issued by the LMA in which paragraph (6) stipulates the rights and wages of the agent for the administrative services performed by him on behalf of the participating

\footnotetext{
${ }^{14}$ Event of Default: The condition or situations in which the Bank is entitled to early termination of the loan or taking action to mitigate the risk (Adams, 2013).

15 Note: These tasks were summarized by researcher Al-Khatib (2015) and are derived from the texts of the proposed model contract (LMA), which can be referred to in detail in Wright, Sue (2006), p211-212).
} 
lenders, as stipulated in paragraph (10) of the same article to the obligation of the lenders to indemnify the agent bank for any liabilities, losses or damages caused to him as a result of his performance of the acts entrusted to him (Wright, 2006).

\subsubsection{The Resignation or Dismissal of the Agent Bank}

The model contract of the LMA in paragraph (11) of Article 26 specifies a specific mechanism for the resignation or dismissal of the agent ${ }^{16}$, which can be summarized as follows:

1) The Agent may at any time provide notice of his resignation to the Lenders and the Borrower. Upon receipt of such notice, the lenders, in consultation with the borrower, have the right to appoint a successor to the agent.

2) The agent may also be removed by an agreed majority of the lenders, as provided in the agreement, at any time by giving written notice to the agent and the borrower 30 days prior to his dismissal. The main lenders - in consultation with the borrower - appoint a successor to the agent during this period and bring the written approval of the successor to accept.

3) If the successor is not appointed by the lenders or the successor does not accept such appointment within 30 days after the agent submits a notice of resignation or dismissal notice, the renegotiating agent on behalf of the lenders is entitled to appoint a successor to the qualifications set out in this agreement.

4) Upon the appointment of a successor to the agent, he shall be granted all rights, powers, privileges and duties relating to the former agent. The former agent shall be exempted from all his duties and obligations set out in this agreement or in the loan documents.

5) The fees payable by the borrower to the successor remain the same as the fees paid to the former agent unless otherwise agreed (Wurst \& Faltischek (2014, P58), Wright (2006, p215).

\subsection{The Legal Status of the Agent Bank in the Syndication Loan}

In this topic the researchers discussed the Juristic views that have dealt with the subject of the legal status of the bank agent in the syndicate loan in the first requirement, and then look at the position of the model contracts issued by the specialized unions such as the LMA of this issue in the second requirement, then the position of the Anglo-Saxon judiciary on this issue is clarified in a third requirement. The fourth requirement discussed this problem in the light of Jordanian law.

\subsubsection{The Juristic Views Examined in the Subject of the Legal Status of the Agent Bank}

The agent bank is appointed by the banks and financial institutions involved in the syndication loan to act on its behalf as an administrative agent, often chosen by lenders in consultation with the borrower, or the bank appointing itself to act as agent (Mugasha, Agasha, 2007), (Wight, 2009), (Adams, 2014).

There is no disagreement in Anglo-Saxon jurisprudence on the fact that the bank agent in a syndicated loan is an agent of the lenders and not an agent of the borrower (Shutter (2010).

But the jurisprudential dispute over whether this bank is a real agent with all the legal meaning of the phrase and therefore the provisions of the Agency's laws, or is it a special agent?

This question raised a great legal controversy during the 1980s and 1990s. Professor Mugasha points out in a special study ${ }^{17}$ that the subject of the Agent bank and its legal status and therefore the responsibility it entails as a result of the previous and current literature and studies shows that this problem is divided in two directions: First, the regulated bank is a True Agent for the Bank's syndicated loan, and the second is that the regulated bank is an agent under a special type of agency.

These two doctrinal trends will be illustrated in two items, as follows:

\subsubsection{The Agent Bank Is the Real Agent of the Banking Group (True Agent)}

In this context, the Bank's agent in the syndication loan is a True agent with all the meaning of the word "Agent", and therefore the provisions of the Agency Law shall apply to it as any other legal agent, and thus it is entrusted with the duties of trust of banks participating in the banking association (Owes Fiduciary Duties to the Syndicate Banks $^{18}$. And that the essence of the duties of trust and confidence in accordance with the law - Anglo-Saxon law - obliges him to act to achieve the best benefits for the party to whom he owes the duties of trust and confedence,

\footnotetext{
${ }_{16}$ The LSTA model contract - applicable in the United States and Canada - contains a similar mechanism in the Replacement of Agent section

${ }^{17}$ (Mugasha, Agasha(1996),The Agent Bank's Possible Fiduciary Liability to Syndicate Banks ‘Canadian Business Law Journal, Vol. 27). Available at: (http//heinonline.org) wed Apr 06:55:12 2014

${ }^{18}$ Among the English jurists who adopted this trend are: Tennekoon and Gabriel, as well as the Australian Professor Lehane,
} 
including the following duties:

a. That the agent does not place himself in a position where his interests contradict the interests of his client.

b. The agent should avoid a conflict of duties (eg, being an agent at the same time for two different consortiums of rival banks competing in their interests, not to enter into a lending relationship with the borrower and, conversely, to relinquish the agency's functions).

c. The agent shall not be entitled to conceal from his client any income or profits that he achieves by executing the duties of this agency.

d. The agent is not entitled to use the confidential information that enables him to view it by performing his duties to achieve his own benefits without his client knowing and obtaining his prior consent (O'Donovan, 2005, pp: 380-382)

\subsubsection{The Agent Bank Is a Special Agent}

The owners of this trend believe that the agent bank in the syndicate loan works under a special type of agency, which does not condemn the duties of the trusteeship and trust of the participating banks unless they are explicitly stated in the syndication loan contract-when the need or circumstances so require- trust and confidence is an exception for him, and the argument of supporters of this trend is based on a number of reasons, including:

a. The obligation of the Agent bank to the duties of the Agency's Law makes this role immaterial and is lost by gravity by the banks and financial institutions that carry out these roles. Because the duties of the agent - in accordance with the law of the agency - will restrict the banks and limit their ability to implement their other commercial services (Shutter (2010)

b. This role should be understood within the context of prevailing market applications, since the idea of the agent bank has been generated by practices and applications prevailing in the financial markets. These applications are based on the assumption that the agent bank should not bear the burdens of the trust duties determined by the provisions of the Agency's laws. The syndicate loan contract when discussing the commission rates of the Agent bank takes into account that the Agent bank will not bear the consequences of the duties of the trust. Therefore, the Agent bank grants specific commissions, and if the parties consider that the Agent bank will bear the consequences of the duties of trust, agency commission rates would have been much higher (Mugasha, Agasha, 1996).

c. In reference to the bank loan contracts, in which the powers granted to the bank are determined by the agent, they are different from those granted to the traditional agent. In practice, it is customary to give the facilitator the syndicate loan agent - administrative powers in the exercise of his duties without granting him the ability to change the legal status of lenders. Its main task is to act as a conduit for the transfer of information and flow of payments between the borrower and the banks of the pool, and as a general coordinator to facilitate decision making by the pool of lenders, while the Agency's laws empower the traditional agents to carry out the work of their clients, and gives them the ability to change the legal status of their clients (Shutter (2010).

d. The obligation of the agent's bank to the duties determined by the law of the agency makes it more liable to the liability claims resulting from negligence of the duties of care imposed - the care required of the secretary is higher than the care required of others. The application of the Agency's traditional provisions to the agent's bank leads to claims of responsibility for breach of the duties of the trusteeship and other duties, such as the duty of disclosure to the participating banks about the borrower's information which may conflict with other duties required by the laws, namely, to maintain the confidentiality of the borrower's information, it may also limit the bank's agent's conduct of business on the pretext of conflict of interest. The agency's duties may prevent him from taking over the work of the agency in other consortium's lending to competing banks or preventing it from offering other loans to the borrower (Shutter, 2010).

For these reasons, the majority of syndicated bank loan agreements have confirmed that the agent bank does not bear the duties of trust and confidence towards the banking group or any participant in the financing of the loan, and that some of the agreements are now called "Administrative Bank" or "Servicing Bank" (Adams, 2014).

\subsubsection{The Position of the Specialized Unions from the Legal Status of the Agent Bank in the Syndication Loan}

With reference to the contractual models of syndication loans issued by the specialized international associations such as the LMA ${ }^{19}$, we find that these models explicitly state that the agent bank is a special administrative agent,

\footnotetext{
${ }^{19}$ Another specialized association called LSTA, established in the United States of America, covers both the United States and Canada, and has developed a number of standards, bases and contractual models for syndicated loans. In reference to the model contract of this Union we find
} 
by including these models, the duties and tasks of the Agent bank are strictly established and it is emphasized that there are no duties of trust and confidence in the bank's business towards the parties to the syndicated bank loan contract, unless expressly provided for in the contract with a view to establishing the international commercial custom that banks have entered into. The agent of the Agent bank in the syndication loan is a special type - the administrative provisions of the regular Agency do not apply to it - that put on the agent the Common Law system and Duties of the trust and confidence (Al-Khatib, 2015).

For example, the text of the model contract (LMA) in article 26 (4) under the title "No Fiduciary Duties" states the following: "(a) Nothing in this Convention shall refer to the agent or the organizer of the job as a trustee or to be entrusted with the duties of the Secretary (Fiduciary) of any other party. (B) The agent or the regulator shall not obligate any lender to justify and clarify any amounts or profits received by him for his own account.

Article (5) of the same article under the heading "Business with the Group" - i.e., with the parties to the syndicated loan agreement - stipulates that: "The agent and the regulator may accept deposits or lend money and generally participate in any kind of Banking or other business with any member of the group. "

A part of the jurisprudence attaches to this clause in the Model Contract (LMA): "The idea that the agent bank is an agent of a particular type and that the origin of its failure to comply with the duties of trust and confidence towards the parties unless expressly provided for in the contract, Most of the jurisprudence and modern jurisprudence, it became common practice that the provisions of this special agency - unlike the traditional agency - decides to exclude the duties of the trust of the duties of the Agent bank, and therefore the Agent bank may enter with the borrower or other parties in any other banking business and that retains the profits it earns without obligation to disclose such information in accordance with the Agency's ordinary law, the agent should not allow his duties to be inconsistent with his personal interests or with the interests of any other client ${ }^{20}$ (Mugasha, 1996), (Mugasha, 2007)

\subsubsection{The Position of Jurisprudence and the Anglo-Saxon Judiciary from the Legal Status of the Agent Bank}

Referring to the Anglo-Saxon legal applications on this issue, one of the oldest judgments, the California Court of Appeals at its ninth session in the United States of America, should be noted in the case between:

\section{Chemical Bank; National Westminister Bank USA v. Security Pacific National Bank}

The case is that in 1983, the Bank of Pacific Security filed an application to join the US Loan Guarantee Agency and successfully secured the classification of all its loans as secured by the Loan Guarantee Authority . In the same year, the Bank provided a loan to a borrower with a value of $\$ 15$ million. A request or statement was submitted to the Loan Guarantee Authority to guarantee this loan. In the same year, the Security Pacific Bank agreed with the plaintiffs to provide a bank loan to the same borrower in the amount of $\$ 25$ million. The loan was divided as follows (60\%) from which the defendant is covered by the (Security Pacific Bank) and (40\%) of the loan amount is covered equally by the Chemical Bank and the National Westminister Bank. The members of the banking group agreed to appoint the defendant (Security Pacific) as the agent of the syndicate loan. The loan contract includes the condition that the bank exempts the agent from liability for any damage to other banks as a result of the negligence of the bank and its employees, unless this is the result of gross negligence or deliberate misconduct.

The loan contract states that the agent's bank is not responsible and is not liable to other banks regarding the obligation or validity of the documents, documents or memoranda submitted by the borrower and that each bank is obliged to carry out the necessary verification on these documents itself. When the defendant (Security Pacific) assumed the functions of the agent were to oblige the contract to verify that the conditions precedent had been

that the provisions of the article on the appointment of the agent in the Model Credit Agreement Provisions (MCAP) issued on 1/8/2012 stipulate that: "Under this document and under the other loan documents, each lender from Lenders Agent (name of administrative agent) to act on his behalf as Administrative agent, and authorizes the administrative agent to carry out such acts on his behalf and exercise all powers delegated to him as an administrative agent, subject to the terms and conditions set out in this document, in addition to granting him reasonable powers to carry out the incidental work that may occur during the period of implementation of this agreement. The provisions of this Article shall be limited only to the acts of an administrative agent ... It is recognized that the use of the term "agent" in this document is not intended to give any meaning of (Fiduciary) or obligations or duties which are subdivided into this meaning and which arise under the provisions of this Law Agency in applicable law (Wurst \& Faltischek, 2014)

${ }^{20}$ However, in all cases, the agent can not earn the borrower or any of the participants in the loan for which he is the agent or because of him any hidden profits or benefits other than those specified in the contract. The Bank shall not be entitled to any special benefit from the amounts or money pledged or placed in its possession as agent of the Syndicated. And can not use these funds to his advantage or make profits by renting or investing in any way. And does not have the right to accept any bribes or gifts from either the borrower or other interested parties of any kind, and in the event that he does so, he shall expose himself to legal liability for breach of the duties of the trust towards the client. (O'Donovan, 2005) 
met to enable the borrower to withdraw the loan. The officer in charge of the process of verifying these conditions - and without consulting the opinion of the legal advisor - decided that the preconditions are complete, and that it was unnecessary to release a statement or request in order to secure the entire loan in the name of Security Pacific as an agent of the syndicated bank loan. The responsible officer justified this by stating that Security Pacific had obtained a certificate from the Deposit and Loan Guarantee Authority that all His loans are guaranteed, and that he had recently applied to this entity to secure the previous loans - to the same borrower - of $\$ 15$ million, and concluded that such guarantees were sufficient and no need to file a new application. After a period of time the borrower was bankrupt, the bankruptcy court decided that the syndicated bank loan of $\$ 25$ million was not fully guaranteed, because the agent's bank had not applied to the loan guarantor to secure the loan when the contract was concluded. However, as Security Pacific classified all its loans as guaranteed, its entire share in the syndication loan was $60 \%$ of the loan amount. When Security Pacific received its $60 \%$ guaranteed share of the syndicated loan, $40 \%$ transferred it to the two banks participating in the syndication loan, but this solution was not satisfactory to the two participating banks. The lawsuit at the Federal Court of Cassation (California, District 9) is based on Gross Negligence.

In considering the facts of the case, the Court found that the failure of the Bank to provide the security agent (Security Pacific) to the required loan guarantee to the full value of the syndicated loan constitutes a gross negligence that requires compensation. However, when the decision was appealed, the Court of Appeal reserved the decision of the Court of First Instance and decided that the responsibility of the agent's bank should be based on the fact that the agent's bank owes the participating banks the Fiduciary Duty. The Court of Appeal has ruled that the defendant bank is the agent of the participants. It is recognized that the duties of the legal agent are part of the duty of trust and trust. However, he is not liable in the face of the plaintiffs despite the fact that he has violated the duties of the trust. Although he is not liable in the face of the plaintiffs, despite the fact that he has violated the duties of the trusteeship and trust in the existence of a provision in the bank loan agreement that exempts him from liability under the "waiver of liability" clause, which relieves him of liability only if it is the result of gross negligence or intentional misconduct ${ }^{21}$. It concluded that the conduct of the defendant was negligent, but that negligence did not amount to gross negligence or intentional misconduct ${ }^{22}$.

This decision raised a wave of controversy and criticism by the jurisprudence and institutions working in the organization of syndicated bank loans because the Court of Appeal considered that the Agent bank owes the duties of trust and confidence to participating banks - that is, it was considered a real agent and not an agent of a special kind - Where a part of the jurisprudence comment on this decision saying: "The decision issued in this lawsuit resonated in the world of international finance, since it was considered that the bank agent originally condemns the duty of trust and confidence (Fiduciary Duty) of banks participating as a traditional agent! Is consistent with market applications and norms ${ }^{23}$ (Mugasha, 1996), (Al-Khatib, 2015).

However, the US courts have reversed their previous decision and taken the correct view in the jurisprudence that the Agent bank is considered an agent of a special kind and is not bound by the duties of honesty and trust towards the participating banks. Among these cases was the judgment of the Arab International Investment Bank case against the National Bank of Maryland in 1993. Banque Arabe et Intrenational D'Investement v. MaryLand Nat'l Bank (1993)

In which the Court of Appeal in New York decided in its second session that: "In general, banking relations are not seen as forming close relationships that lead to the creation of the duty of care and the duties of trust among themselves because they are sophisticated financial institutions. These financial institutions do not usually base their financial relations on the basis of their rapprochement relationships, but rather on an arm's length basis. This principle applies to syndicated loan agreements and syndicated loans, It is based on trust and confidence, accordingly, the regulator of both the bank and the agent does not condemn the original duties of the Secretariat

\footnotetext{
${ }^{21}$ In other words, the Court of Appeal applied to the ordinary provisions of the Agency with the possibility of applying the terms of exemption from liability and did not consider it to be a special agent.

${ }^{22}$ This decision was summarized, noting that the resolution is published at the following link: http://www.leagle.com/decision/199439520F3d375_1340.xml/CHEMICAL BANK

${ }^{23}$ This decision was considered important because it was the first judicial decision in the United States to deal with the bank's responsibility for bank lending in the face of the participating lenders. The US courts have already issued a number of cases concerning the responsibility of the Agent bank, but these issues were not related to syndicated loans, but were related to loan participations. In fact, these loans differ in terms of form and role Procedures and legal responsibility and loans of the banking group. Among the most famous cases concerning the responsibility of the bank's agent in the syndicated loans are the following:

Women's Federal Savings and Loan Assn. v Nevada National Bank (9th) Cir. 1987 \& First Citizens Federal Savings and Loan Assn. v Worthen Bank and Trust (9th) Cir. 1990 (Mugasha, Agasha (1996), pp. 403-408). ( Hall, Thomas J \& Pergament, Benjamin D(2004),p421),
} 
of the participating banks unless the text in the holding facilities otherwise expressly and without ambiguity "(Al-Khatib (2015)

(http://law.justia.com/cases/federal/districtcourts/FSupp/819/1282/1965458)

In another case considered by the New York Court, a case involving:

New Bank of New England v. Toronto-Dominion Bank (1991)

This court decided decisively that: "[No] basis for reading the duties of trust and trust or any other duties subdivided into the syndication agreements of the bank, because it concluded between institutions of advanced lending" (Hall, Thomas \& Pergament, Benjamin, 2004).

In another case, the Louisiana Court of the United States, between Keenan v Donaldson, Lufkin \& Jerente, Inc. (2009), which states that one of the lenders involved in a syndicated bank loan has filed this action against the agent's bank claiming that the bank breached trust and confidence obligations when conducting other lending operations to the same borrower. When the Louisiana Court considered the case, it decided that there were no duties of trust owed by the agent to the member involved in the syndication loan. There is no evidence that a member of the consortium should have acted in favor of lenders under the duty of trust and confidence (Wurst, Jeffrey \& Faltischek, Ruskin (2014).

\subsubsection{Legal Status of the Agent Bank in Light of Jordanian Laws and Legislation}

In order to reach the legal status of the agent bank in the syndication loans within the scope of the Jordanian law, it is necessary to state the system of laws that governs in Jordan (first), and then determine the legal status of the bank agent (second).

\subsubsection{The Legal System Governing the Syndication of Bank Loan in Jordan}

Bank loans are Multi-Bank Transactions. In which two or more financial institutions cooperate, to provide funding to a borrower (Mugasha, 2007) and (O'Donovan, 2005).

Although many of the world's legal systems allow non-bank financial institutions to enter into syndicated bank loans, this does not injure banking operations with distinction. Therefore, the syndicate's loans do not come out as a bank credit instrument, but what distinguishes it from other tools or banking operations offered by individual banks is that it cooperates with a number of banks and financial institutions. This means that the laws that govern and regulate them are the laws governing the business Banks of legislation and norms and sources of guidance, such as Judicial and jurisprudential ${ }^{24}$ (Khatib, 2015).

However, by examining the banking system in force in Jordan, we find that it did not organize bank loan agreements under explicit and direct provisions ${ }^{25}$, however, the banking system in Jordan does not regulate bank loan agreements under explicit and direct provisions.

Since the syndication loan contracts arose under the common law system, which relied mainly on custom and case law in its law, the legislator did not regulate its provisions under special legislation. In countries that adopt the Latin system, which relies on written legislative rules or countries that adopt a mixed system, as in Japan, legislators have introduced some legislation regulating the loans of the banking association. For the regulator, the Polish legislator set special provisions in the banks law to deal with loans of the banking association. The Chinese legislator has also set out special instructions governing the provisions of syndication loans, and the Japanese legislator has established a code of conduct that includes a number of criteria that should be followed by syndicated banks and proxies in syndication loans (Khatib, 2015).

\footnotetext{
${ }^{24}$ Banking is governed by a system of laws that has been referred to as "banking law": "a modern designation of the legal rules governing the activity of banks" (Awad, Ali Jamal al-Din, p. 15 "Banking Law" consists of: "the set of legal rules governing banking operations, whether they originate from legislation or custom, treaties, model contracts, regulations and instructions set by banks" (Akeili, Aziz, 2010, p. 296). In reference to the system of banking legislation in force in Jordan, we find that it consists of a number of legislations that include: "The assets of banks to practice their work and control them through texts contained in general legal rules contained in several branches of law such as corporate law, income tax law, Banks, the Central Bank Law, the Currency Control Law, the Money Exchange Law, the Securities Law, the Law on the Status of Immovable Property for Insurance of Religion, and other laws aimed at setting general rules for banking work (Kilani, Mahmoud, 2008) P. 29).

${ }^{25}$ Since the syndication loan contracts arose under the common law system, which relied mainly on custom and case law in its law, the legislator did not regulate its provisions under special legislation. In countries that adopt the Latin system, which relies on written legislative rules or Countries that adopt a mixed system, as in Japan, legislators have introduced some legislation regulating the loans of the banking association. For the regulator, the Polish legislator set special provisions in the banks law to deal with loans of the banking association., And the Japanese legislator has established a code of conduct that includes a number of criteria that should be followed by syndicated banks and proxies in syndication loans (Khatib, 2015).
} 
The syndicate loan is considered indefinite because the Jordanian legislator did not belong to it under a specific name or was not regulated by special provisions of the law. Therefore, it is subject to its composition and the effects it entails on the general rules prescribed for all contracts. It is one of the commercial banking contracts commercial in nature -, Because it falls within the framework of the banking operations stipulated in Article (6/1 / D) of the Jordanian Trade Law ${ }^{26}$ (Khatib, 2015).

It is known that all transactions of exchange and transactions of public and private banks are considered to be commercial in nature for the bank or the cashier, and for the bank's customer or the cashier, it is not considered business for him unless he is a merchant and work has been done with regard to his trade (Uqaily, 2008).

This means that if the borrower is a trader, the contract is deemed commercially viable for him or her, and if the borrower is not a merchant, the contract is a civil one (Al-Atair, 1993). However, this case, which was decided by the Jordanian Trade Law, led in practice to difficulties for banks in some contracts in case the borrower is not traded as the contract for him will be civil. The Jordanian legislator decided to settle the matter in Article (92/e) of the Banking Law when all banking and financial activities carried out by banks were made commercial by virtue of their own nature, regardless of the status of the client contracting with the bank, whether civil or commercial $^{27} 28$.

The Jordanian Trade Law stipulates in Article (2) that: "1. If the provisions of this Law are not applicable, the provisions of the Civil Code shall apply to commercial articles." 2. The application of these provisions shall be only in proportion to their agreement with the principles of commercial law. Article 122 of the Trade Law stipulates that: "Banking operations not mentioned in this section shall be subject to the provisions of the Civil Code which are related to the various contracts (arising from the said operations or the contracts that characterize such transactions)."

Articles (2 and 122) of the Trade Law show that the Jordanian legislator referred all transactions and bank contracts not mentioned in the Commercial Law to the provisions of the Civil Code. The provisions of the Civil Code are therefore an integral part of commercial law in respect of contracts not mentioned or unregulated in commercial law.

But the question that arises is whether civil rules - by virtue of this referral - precede the rules of commercial custom or banking custom?

To answer this question, reference must be made to the provisions of Articles (2), (3) and (4) of the Jordanian Trade Law.

Article (2) of the Jordanian Trade Law relating to the assignment to the Civil Code has already been referred to. Article 3 states: "If there is no legal provision applicable to the judge, it shall be guided by case law, jurisprudence of jurists. While article 4 states: "1. In determining the effects of a business, the judge shall apply the prevailing custom, unless it appears that the contractors intended to violate the provisions of custom or the custom was contrary to the mandatory legal texts. 2. Private and local custom are weighted on the general custom."

We note that the Jordanian legislator in Article 3 of the Commercial Law has established the commercial custom and thus the banking custom as a guiding source. He has placed it at the bottom of the list of sources that the judge can be guided by, but he repeats in article 4 that the judges in determining the effects of the business - any obligations of the parties - apply the prevailing norm. It is therefore possible to understand from the reading of these articles ( 3 and 4 ) that the judge should apply the prevailing custom as a guide. If he chooses to apply it, the custom should not be contrary to the will of the parties if they agree to explicitly contravene the contract, and not

\footnotetext{
${ }^{26}$ In reference to the Trade Law No (12) of 1966, we find that the Jordanian legislator has differentiated between civil and commercial work. The business is subject to the provisions of the Trade Law and it has provisions that are commensurate with the nature of commercial transactions that aim at profit and are characterized by speed and credit. Article (6) of the Jordanian Trade Law gave a general description of some businesses by their nature or by virtue of their own nature. "These acts are repulsive but commercial ... they are those which, if signed even once, regardless of the status of those who carried them out, Merchant or non-merchant "(Kilani, Mahmoud (2009). The Jordanian legislator has classified money exchange and swap transactions and transactions of public and private banks in the business sector by virtue of their own nature. Article (6/1/1) states: "The following acts are by virtue of their own business: (d) Financial swap and public and private banking transactions ".

${ }^{27}$ The Jordanian Court of Cassation affirmed this in many of its decisions: "The provisions of Article 92 / e of the Banking Law and its amendments No. 28 of 2000 make it clear that all banking and financial activities are considered commercial by virtue of their own nature, With the Bank and the provisions of the Trade Law in force shall apply to them "(Jordanian Discrimination Decision, No. 129/2009, 13/8/2009, Adalah Publications)

${ }^{28}$ Article (6) Article (1) Paragraph (d) of the Jordanian Trade Law
} 
to be contrary to the provisions of the compulsory law.

A part of the Jordanian jurisprudence tried to explain this text: "The apparent interpretation of the text of Article 3 of the Jordanian Trade Law may not be consistent with what the legislator wanted." It is true that the commercial custom was mentioned in the last text of the said article, But this does not mean that the legislator wanted in this census a statement to include these sources as sources of guidance to the judge to be consulted or guided by its rules in dealing with the conflict, so we can say that it is not included in the text Article 3, but leaves the matter to the judge may be guided by custom in the case of a commercial law, before the introduction of case law or the jurisprudence of the jurists or the requirements of fairness. As we see from the appearance of the text, it is not allowed to be customary in Jordanian law as a source of legislation in practice (Sami, 1997).

The answer to the question raised above is that the text of the assignment contained in Article 2 in addition to the provisions of Articles 3 and 4 of the Jordanian Trade Law make the rules of civil law an integral part of the Trade Law. At the same time, the rules of law Civil ranked on the banking custom.

And that what confirms this result that there is a view in the jurisprudence has discussed this problem by saying: "In light of this reference to the provisions of the Civil Code, if the origin requires the introduction of the application of the customary rule of trade on general civil provisions, the question that arises before us is the fate of the rule of customary banking and its location from application? ... Indeed, the explicit reference to the provisions of the Civil Code makes these texts an integral part of commercial law ${ }^{29}$ (Dweidar, 1997) Principles of Commercial Law, pp. 28-29. The civil service referred to it ... is applying to the customary banking regulation, the provisions of the Civil Code are therefore governed by the subject of assignment, which is a form of so-called contract whose provisions apply to the banking process concerned (Dweidar, 2001), Legal System of Commerce, p. 311).

In fact, the text of Article (2) of the Jordanian Trade Law and other articles of reference to the Civil Code contained in various parts of the Jordanian Trade Law, in addition to Articles ( 3 and 4) of the Jordanian Trade Law which specify the rank of custom in the business Constitute a conspicuous legislative fault requiring the intervention of the legislator to avoid it by putting a similar text to article 2 of the Egyptian Trade Law, which was more accurate and conciliatory. Because the civil rules do not fit in all cases with business and banking, because the work and banking activities, whether applied in Jordan or in other countries that follow the same approach is not subject to the majority of legislative regulation, but it is a result of habits and customs that the banks have followed, therefore, the banking custom should come directly after the Juridical legislative texts in terms of rank (Khatib, 2015).

\subsubsection{Determine the Legal Status of the Agent Bank in Light of the Legal System in Force in Jordan}

In light of this legislative reality in Jordan, what is the legal status of the agent bank? In other words, what rules do we use to determine the legal status of the agent bank? This is what will be answered in this item.

The Jordanian legislator did not regulate the loans of the banking group and did not specify the obligations of its parties under special provisions, either in the Banking Law or in other legal legislations governing banking.

Therefore, reference will be made to some of the rules contained in the Jordanian Trade Law and to the rules in the Jordanian Civil Code, because the Trade Law has included some provisions regulating the work of commercial agents or commission agents, which referred in some of its provisions to the Agency's provisions in the Civil Code. This study can not discuss all the provisions contained in the provisions of the commercial agency or the regular agency because this requires a lengthy study, but the researchers will review some of the rules and general concepts to examine their suitability to determine the legal status of the bank agent in the loans of the banking community.

In reference to the provisions of the Agency in the Trade Law, we find that Article (80) of which provides as follows: "1. The Agency shall be commercial when dealing with commercial transactions. 2. In particular, this contract shall be called commission agency and shall be subject to the provisions of the following chapter when the agent must act in his own name or under a commercial address for the account of his assignee. 3 . When the agent must act in the name of his client, his rights and obligations shall be subject to the provisions contained in this regard in the Civil Code.

It is clear from this article the following, (1/80) of this Article, decided that when the Agency is concerned with commercial transactions, the Agency shall be commercial, and by applying this rule to the Agent bank in the syndicated bank loans, we shall find that the agent's business is focused on banking business and therefore his

29 The text discussed by Dr. Hani Al-Dwaidar is similar to the text of the Jordanian Commercial Law. 
agency is considered commercial.

But this commercial agency does not apply to the provisions of the Agency Commission, which is regulated by the Trade Law as it is clear from the text of the second paragraph of the same article (80), which stated that the provisions of this "chapter" of the Commercial Law regulates the contract agency commission, Commission when the agent acts in his own name or under a commercial address for the account of his assignee.

Article (87) returns to indicate who the agent of commission by saying is: 1- The commission agent is the one who takes upon himself to hold his own name, but for his client's sale and purchase and other transactions for commission. 2. The Agency's rules shall apply to the commission contract of the Agency, subject to the provisions set out in this chapter.

We note from the foregoing that this type of agency does not apply to the agent bank in the syndication loans ${ }^{30}$.

Since the law of commerce in the various texts related to the assignment referred to the contract of the Agency in the Civil Code, it is necessary to refer to the articles regulating this contract in the Civil Code to determine whether we apply the provisions of the Agency provided for in the Jordanian Civil Code? or the provisions of the Agency Commission prescribed by the Commercial Law? or the rules of international banking?

\section{Conclusion}

After completion of this study, a number of conclusions and recommendations were reached as follows.

\subsection{Results}

1) The bank's lending operations do not, in fact, emerge as a form of bank credit, but are provided by a number of banks and financial institutions.

2) The Agent bank is appointed by the participating lenders who have signed the syndicated loan agreement, so it is considered an agent for the lenders and not an agent for the borrower.

3) The Agent bank shall commence its work after the signing of the syndication loan agreement after the end of the role of the regulated bank.

4) The correct Anglo-Saxon legal and judicial orientation is that the bank is the agent of an administrative agent of a special type and therefore does not apply to the traditional provisions governing the Agency. But banking conventions and this is what has been adopted by specialized international federations such as the LMA and others in their model contracts. By confirming that the agent's bank does not originally owe any party to the bank loan agreement the obligations of trust and confidence imposed on ordinary agents, unless the Agent bank expressly places the agent himself - in a contractual or realistic manner - in a position that makes him owe obligations to one of the parties the agency by which the duties of the trust.

5) With regard to the situation in Jordan, banking operations are considered to be commercial operations by nature and are therefore governed by a set of commercial laws, which have been referred to as the banking system. However, the Jordanian legislator has not enacted any special provisions regulating the bank's loans, the Trade Law referred to the operations and commercial contracts that were not organized into the Civil Code.

6) In light of this legislative, jurisprudential and judicial vacuum related to syndications in Jordan and other Arab countries, there is nothing to prevent the adoption of the correct jurisprudential and Anglo-Saxon jurisprudence adopted by the banks and specialized federations to become the banking custom in this field, Which is considered to be a special Agent bank unless the Bank expressly places the agent himself - in a contractual or realistic manner - in a position that makes him owe to one of the parties the duties of the Agency for which the secretariat's trust is subdivided.

\subsection{Recommendations}

1) States shall establish legislation regulating the syndication of the syndication loan, including Jordan, and organize it within their own legislation regulating the operations of banks, specifying the duties and obligations of leading banks - the regulator and the agent.

2) In the absence of legislation, the banks that assume the role of the agent bank must:

\footnotetext{
${ }^{30}$ Article (85) of the Trade Law states: "When the contract includes at the same time the characteristics of the Agency and the basic elements of the contract of employment as in the contracts that arise between the dealer and his various agents such as the local representative, the authorized representative, the Agency shall apply the rules of the contract of employment in relation to the merchant's relations with his agent and the rules of the Agency shall apply in respect of third parties. " Thus, it is clear that this type of agency is completely different from the bank's agent agency in the syndication loan.
} 
- $\quad$ The Agent bank shall discuss with the parties the bank loan contract the tasks entrusted to it with great care, with emphasis on listing them in the contract in detail before signing the facility contract - the syndication loan contract.

- $\quad$ To make sure that any texts received by him are exempt from his duties as an administrative agent, such as the obligation to perform a thorough examination to ensure the correctness and integrity of the information, financial statements, documents received by the borrower to be submitted to the participating lenders; to ensure that there are explicit provisions confirming that it is not his duty to analyze the borrower's credit information, and that it is not more than an apparent examination of the integrity of the bonds and documents submitted to him by the borrower, that the analysis of credit information and assurance of integrity and authenticity The documents are the duty of each participating bank independently.

- $\quad$ The agent bank shall ensure that there is explicit provision in the credit facility agreement - the syndication loan contract - confirms that there are no implied duties other than those expressly provided for in the contract.

- $\quad$ The agent bank shall ensure that there is an explicit provision in the facilitation agreement confirming that the law and the provisions of the ordinary agency do not apply to him, and that what applies to him are the local and international banking conventions in this field.

- $\quad$ The agent bank shall ensure that the contract does not prevent him from practicing any activities or other banking operations with the borrower, or prevents him from taking over the bank's agent's job with other banking groups and reserving any provisions that prevent him from doing so because such a reservation gives him the opportunity to take care of his own interests placing it in an appropriate legal position and relieving it of the consequences of civil liability.

- $\quad$ The agent bank should perform its duties with high professionalism and, once it takes over the agency's work in a bank loan, undertake a comprehensive reading of the agreement, summarize it, define its duties, understand it accurately and set the dates of the reports and procedures required in a special agenda.

- Ensure that all the preconditions specified in the Facility Agreement are complete before allowing the borrower to make the first draw or withdraw the loan amount, and make sure that the duties specified in the contract are performed regularly. And to follow up on the borrower's position and compliance with the terms and conditions of the loan contract within the limits and standard terms set forth in the agreement, to prepare reports and send them on time to the participating lenders shall inform them of any defect or breach committed by the borrower during the lifetime of the loan.

\section{References}

Abdullah, Kh., \& Al- Trad, I. (2011). Banking Operations Department: Local and International (1st Issue). Dar Wael Publishing and Distribution, Amman, Jordan.

Abubakari, H. (2012). Alignment of the Interest of Lenders in a Syndication Agreement: Is It Truly A concept in Search of a Principle? CEPMLP Annual Review, 16.

Adams, D. (2014). Banking and Capital Market, Publisher. College of Law Publishing, UK. p: 24.

Al-Khatib, M. (2015). The adequacy of the general rules of civil liability in determining the bank's leading responsibility in the loan of the Syndicated banks.

Al-Sous, K. (2009). Joint Loans and their Impact on Risk Distribution, Master Thesis, Damascus: Damascus University, Faculty of Economics.

Altunbas, Y., Gadanecz, B., \& Kara, A. (2006). Syndicated Loans. Palgrave Macmillan, London, UK. P : 8 ,15, 21. https://doi.org/10.1057/9780230597235

Aqel, M. (2006). Banking Perspectives, issue 2, printed on Arab Bank Tunnel, (nd), Amman, Jordan.

Armstrong, J. (2003, June) The Syndicated Loan Market: Developments in the North American Context, Working Paper 2003-15, Bank of Canada.

Bradley, C. (2010). Issues in International Syndicated Loan Agreements. Retrieved from http://blenderlaw.umlaw.net

Clarke, L., \& Farrar, S. (1982). Rights and Duties of Managing and Agent Banks in Syndicated Loans to Government Borrowers. University of Illinois Law Review. Retrieved from http://heinonline.org

Daoud, M. (2010). Bank Group Loans - Professional Diploma Program in Banking Credit, Institute of Banking Studies, Amman, Jordan. 
Fight, A. (2004). Syndicated Lending. Elsevier Butterworth-Heinemann, Oxford, UK.

Godlewski, Ch. (2009). Duration of Syndication Process and Syndicate Organization.

Hall, Th., \& Pergament, B. (2004). In no Uncertain Terms: The Importance of Defining The Duties of Lead Lenders In Multi-Lender Transactions. The Banking Law Journal, 121(5).

Hallak, I., \& Schure, P. (2009, February 27). Why Larger Lenders Obtain Higher Returns: Evidence from Sovereign Syndicated Loans, CAREFIN Research Paper No. 4/09.

Lehane, J. (1982). The role of Managing and Agents Banks: Duties, Liabilities, Disclaimer Clauses. INT'L FIN L. REV 235.

Leichtling, M., Dubin, B., \& Wong, J. (2010). Commercial Loan Documentation Guide. Publisher: LexisNexis, Vol. 1, CA., USA.

Maskara, K. (2006). Participation of Investment Banks and Non-Bank Financial Institutions in Syndicated Loans. Retrieved from http://papers.ssrn.com/sol3/papers.cfm? abstract_id=893071

Michael et al. (2010). The collapse of international bank finance during the crisis, BIS Quarterly Review. Retrieved from http://www.bis.org/publ/qtrpdf/r_qt1009f.pdf

Mugasha, A. (1996). The Agent Bank's Possible Fiduciary Liability to Syndicate Banks. Canadian Business Law Journal, 27. Retrieved from http//heinonline.org

Mugasha, A. (2007). The Law of Multi-Bank Financing (Syndicated Loans and the Secondary Loan Market). Oxford University Press, London, UK.P: 2.

Odianosen, E. (2005). How Does a Syndicated Agreement Deal with the Conflicting Interests of Lenders? CEPMLP Annual Review, 8.8 Retrieved from http://www.dundee.ac.uk/cepmlp/gateway/index.php?news=28025

O'Donovan, J. (2005). Lender Liability. Sweet \& Maxwell, London, UK.

O'Sullivan, J. (1992). The Roles of Managers and Agents in Syndicated Loans. Journal of Banking and Finance Law and Practice, 162, 163-4.

Qu, Ch. (2000). The Fiduciary Role of the Manager and the Agent in a Loan Syndicate. Bond Law Review, 12. Retrieved from http://epubications.bond.edu.au/blr/vol12/iss1/7

Rhodes, T. (2009). Syndicated Lending : Practice and Documentation (5th ed.). Euromoney Books, London, UK, P: 17 .

Shukri, M., \& Awad, M. (2004). International Finance: Foreign Currencies and Derivatives between Theory and Practice, Dar Al Hamed Publishing and Distribution, Amman, Jordan.

Shutter et al. (2010). A Practitioner's Guide to Syndicated Lending (1st ed.). Sweet \& Maxwell, London, UK.

Skene, G. (2006). Arranger Fees in Syndicated Loans, A Duty to Account to Participant Banks? Penn State International Review, 24(1).

Twinamatsiko, F. (2010). What Is the Role of Loan Syndication in Project Financing? Retrieved from http://www.dundee.ac.uk/cepmlp/gateway/files.php

Wight, R. (2009). The LSTA'S Complete Credit Agreement Guide. Mc Graw-Hill , USA,P: 485.

Wood, Ph. (2007). The Law and Practice of International Finance Series, Vol. 3, International Loans, Bonds, Guarantees, Legal Opinions, $2^{\text {nd }}$ Edition, Sweet \& Maxwell, London,UK.

Wright, S. (2006). International Loan Documentation. Palgrave Macmillan, London, UK. https://doi.org/10.1057/9780230514799

Wurst, J., \& Faltischek, R. (2014). The Syndicate's View of the Agent: Dos and Don'ts; Rights and Maybe Wrongs, Association of Commercial Attorneys-CLE.

\section{Copyrights}

Copyright for this article is retained by the author(s), with first publication rights granted to the journal.

This is an open-access article distributed under the terms and conditions of the Creative Commons Attribution license (http://creativecommons.org/licenses/by/4.0/). 